TITLE:

\title{
EPIBENTHIC OR PLANKTONIC CAPRELLIDS FROM THE ENVIRONS OF TANABE BAY (AMPHIPODA : CAPRELLIDAE)
}

$\operatorname{AUTHOR}(\mathrm{S})$ :

Utinomi, Huzio

CITATION:

Utinomi, Huzio. EPIBENTHIC OR PLANKTONIC CAPRELLIDS FROM THE ENVIRONS OF TANABE BAY (AMPHIPODA : CAPRELLIDAE). PUBLICATIONS OF THE SETO MARINE BIOLOGICAL LABORATORY 1968, 16(4): 281-289

ISSUE DATE:

1968-12-27

URL:

http://hdl.handle.net/2433/175548

RIGHT: 


\title{
EPIBENTHIC OR PLANKTONIC CAPRELLIDS FROM THE ENVIRONS OF TANABE BAY (AMPHIPODA : CAPRELLIDAE) ${ }^{1)}$
}

\author{
Huzio UTINOMI
}

Seto Marine Biological Laboratory, Sirahama

With 5 Text-figures

\begin{abstract}
Caprellids, especially the species belonging to the genus Caprella, are generally epiphytal or epizootic in life, but some of them are occasionally obtained as pelagic, more strictly, tychoplanktonic life. Caprella decipiens, C. gigantochir and C. neglecta, all of which have been found in Tanabe Bay, belong to this category. But, among less-known genera other than Caprella, may some be included in euplanktonic or epibenthic forms. As these examples Protomima imitatrix and Paracaprella crassa found newly in Tanabe Bay may be reckoned, although both are known previously in Japanese waters. A small caprellid tentatively identified as Prellicana minima which is known only from the Gulf of Siam was found on deep basin near Tanabe Bay for the first time.
\end{abstract}

\section{Introduction}

I formerly recorded some caprellids from Tanabe Bay of the southern coast of Honsyu (Hiro, 1937). They are Protogeton inflatus Mayer, Protella gracilis Dana, Caprella acutifrons var. natalensis (correctly C. neglecta MAYER), C. decipiens MAYER, C. fretensis (correctly C. subinermis misidentified), C. gigantochir MAYER, C. scaura Templeton and $C$. simia MAYer. All these caprellids have been found rather commonly in association with algae, bryozoans and hydrozoans occurring there.

Since then, a number of specimens have been accumulated from nearby waters intermittently, and some of them have been recorded together with those from many other localities of Japan (Utinomi, 1947). Very recently Drs Bieri and ToKioka of our Laboratory (1968) deviced a new quantitative trawl named "Dragonet II" and by using this trawl they have collected meiobenthic samples in the environs of Tanabe Bay. As a result, the following caprellids were found effectively among inshore and deep-water samples.

1) Station NS-1 (by top-net of Dragonet II). Off "Sirahama Bungalow", NE of the Laboratory, $1.5 \mathrm{~m}$ deep. Bottom: gravel. Coll. March 12, 1966.

Caprella gigantochir MAYER $1 \hat{\delta}$

C. neglecta MAYER $2 \hat{\delta}$, 1 juv.

1) Contributions from the Seto Marine Biological Laboratory, No. 496 and Studies on Meiobenthos by Dragonet, No. 5 .

Publ. Seto Mar. Biol. Lab., XVI (4), 281-289, 1968. (Article 20) 
C. decipiens Mayer 19

2) Station NS-2 (by bottom-net of Dragonet II). Off "Sirahama Bungalow", NE of the Laboratory, $1.8 \mathrm{~m}$ deep. Bottom: gravel. Coll. March 12, 1966.

C. gigantochir MAYER 1 今

C. neglecta MAYER $4 \hat{o} \hat{o}, 3$ young $\hat{o} \hat{o}$

3) Station 50-1. 1.2 km west of Cape Seto-zaki, $50 \mathrm{~m}$ deep. Bottom: sand with organic detritus. Coll. July 13, 1966.

Protomima imitatrix MAYER 2今 $\delta$

Prellicana minima MAYER 1 o

In addition to these interesting collections, a unique species Paracaprella crassa MAYER, found in plankton samples towed by $\mathrm{Mr} \mathrm{T}$. YAMAMoTo off Ezura near the above-mentioned station NS-1 is also recorded here.

\section{Description of the Species}

\section{Protomima imitatrix MAYER}

(Jap. name: Mukasi-warekara Utn.)

(Figs. 1-2)

MaYer, 1903, p. 22, pl. 6, figs. 10-11 and PI. 9, fig. 56 (Enoura, Suruga Bay); Arimoto, 1929, p. 6, pl. 1, figs. 1-2, 4-6 (Tateyama, Sagami Bay); Utinomi, 1947, p. 69 (Hoza-ura, Gokasyo Bay and Okinosima, Iki Strait).
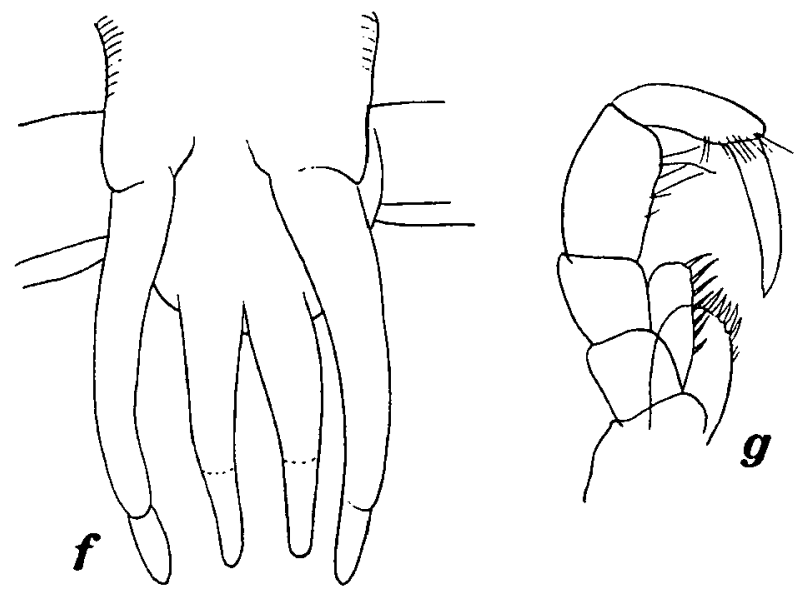

Fig. 2. Protomima imilatrix MAYer. $\delta$ $f$, Abdomen $(\times 210), g$, Maxilliped $(\times 190)$.

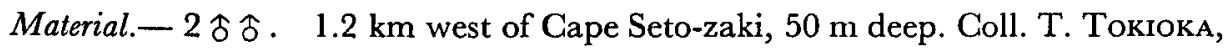
July 13, 1966.

1 $\delta$. Seto (obtained by plankton-net). Coll. I. YamazI, July, 1956. 
Remarks.- This primitive caprellid, having well-developed pereopods 3 and 4, together with elongate gills at their bases and 2 pairs of 2-jointed digitiform pleopods in the abdomen, is perceptively unique, so that might be given only a sketch of appendages for further references.

Habitat and distribution. - As to the habitat, MAYER (1903) only mentions as "Habitus genau wie der einer Proto ventricosa." According to Chevreux et FAGe (1925) Phtisica marina (SlABber) (=Proto ventricosa) is pelagic in European waters. Likewise, I have not met with this caprellid in shallow waters, grasping any algae or other ben-

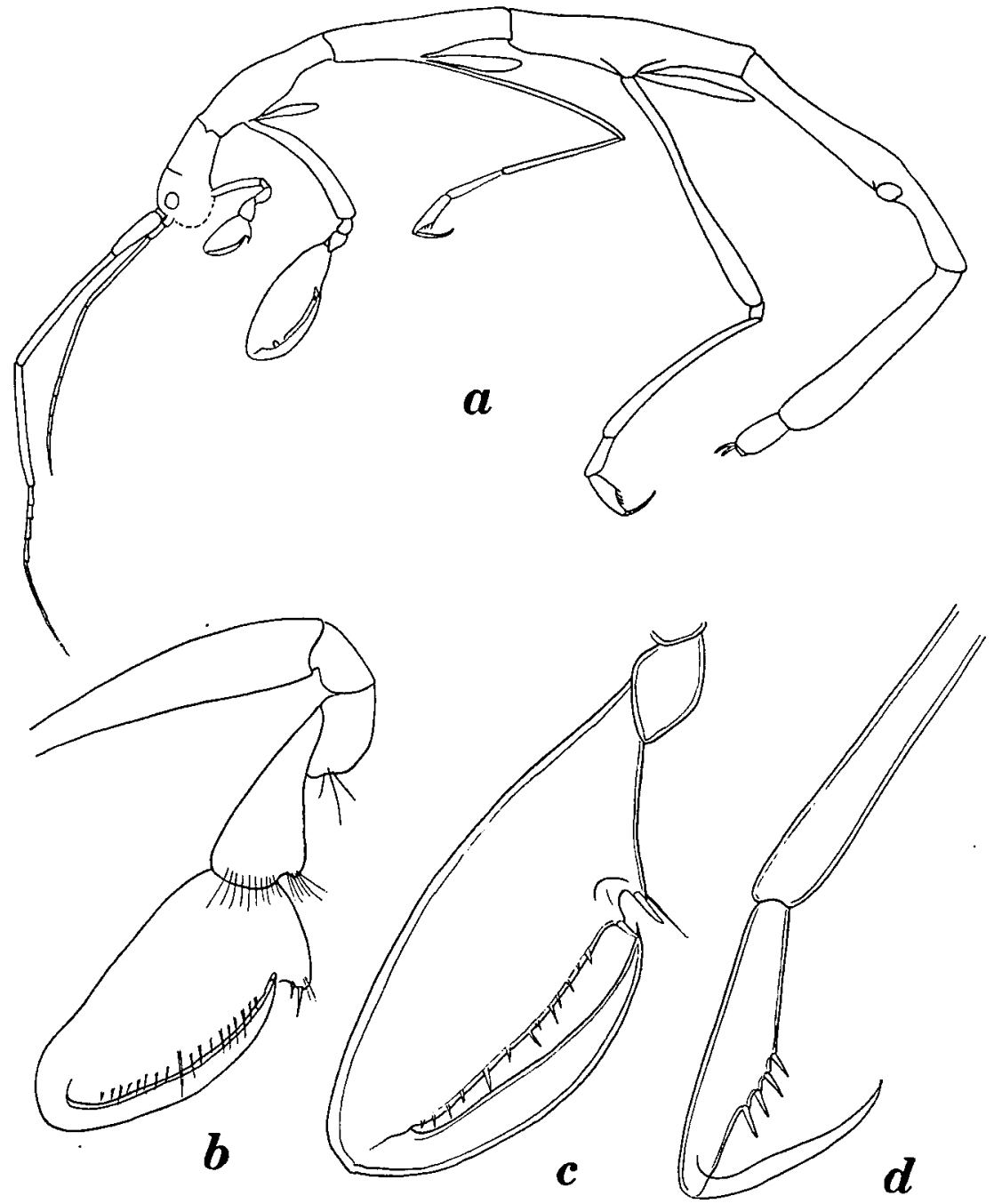

Fig. 1. Protomima imitatrix MAYER, 0

$a$, Lateral aspect $(\times 10) . b$, Gnathopod $1(\times 70) . c$, Gnathopod $2(\times 70) . d$, Distal part of pereopod $3(\times 70)$. 
thic organisms. It appears that the prolongation of body and appendages is better fitted to planktonic life rather than to adhering mode of life.

\section{Prellicana minima MAYER}

(Jap. name: Asinaga-tibi-warekara, nov.)

(Fig. 3)

MAYer, 1903, p. 31, pl. 1, figs. 16-17, pl. 6, figs. 35-37 and pl. 9, figs. 13, 32 and 53.

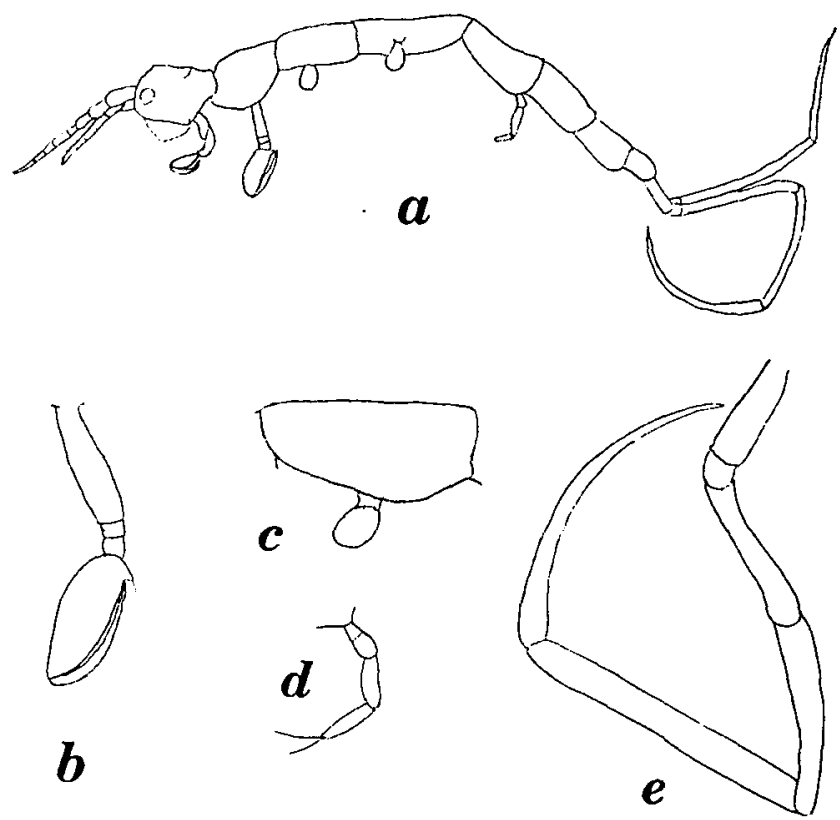

Fig. 3. Prellicana minima MAYer. $\delta$

$a$, Lateral aspect $(\times 33)$. b, Gnathopod $2(\times 96)$. c, Pereonite 4 with gill $(\times 96)$. $d$, Pereopod $5(\times 96)$. e, Pereopod $7(\times 96)$.

Material.—1令. $1.2 \mathrm{~km}$ west of Seto-zaki, $50 \mathrm{~m}$ deep. Coll. T. Tokıoka, July 13, 1966.

Description. - Body slender, smooth, without spines. Length $1.6 \mathrm{~mm}$.

Head moderately large, fused with shorter pereonite 1 by slight oblique suture; eyes rather large. Antenna 1 a little longer than cephalon, consisting of plump peduncle and slender flageilum. Antenna 2 slightly shorter than antenna 1, apparently lacking sensory setules.

Gnathopod 2 attached to center of pereonite 2, bears narrow, oblong hand; palm evenly curved, with a small proximal projection. Gnathopod I like gnathopod 2 in shape but slightly smaller.

Gills on pereonites 3 and 4 very small, oval in form; no pereopods appended. 
Pereopod 5 rudimentary, only $0.2 \mathrm{~mm}$ long, apparently 3-jointed, but in fact basal one obscurely divided into 2 parts.

Pereopod 6 missing. Pereopod 7 normal, $0.9 \mathrm{~mm}$ long; propodus and dactylus very elongate, not setose, lacking grasping spines.

Abdomen not examined.

Remarks.- The above description is incomplete, because the single specimen was regrettably lost by careless treatment during examination, so that much to be elucidated remains.

At first I was inclined to assign it to either the genera Caprellinoides Stebbing (1883) or Parvipalpus Mayer (1890), but later noticed that it agrees with Prellicana minima MAYer (1903) reported only from Koh Kauv, 10 fathoms and Koh Chuen, 15 fathoms (both the Gulf of Siam). If this tentative identification proves to be correct, this may be the second record of occurrence outside of the type locality.

\section{Paracaprella crassa MAYER}

(Jap. name: Ikubi-zvarekara Utn.)

(Fig. 4)

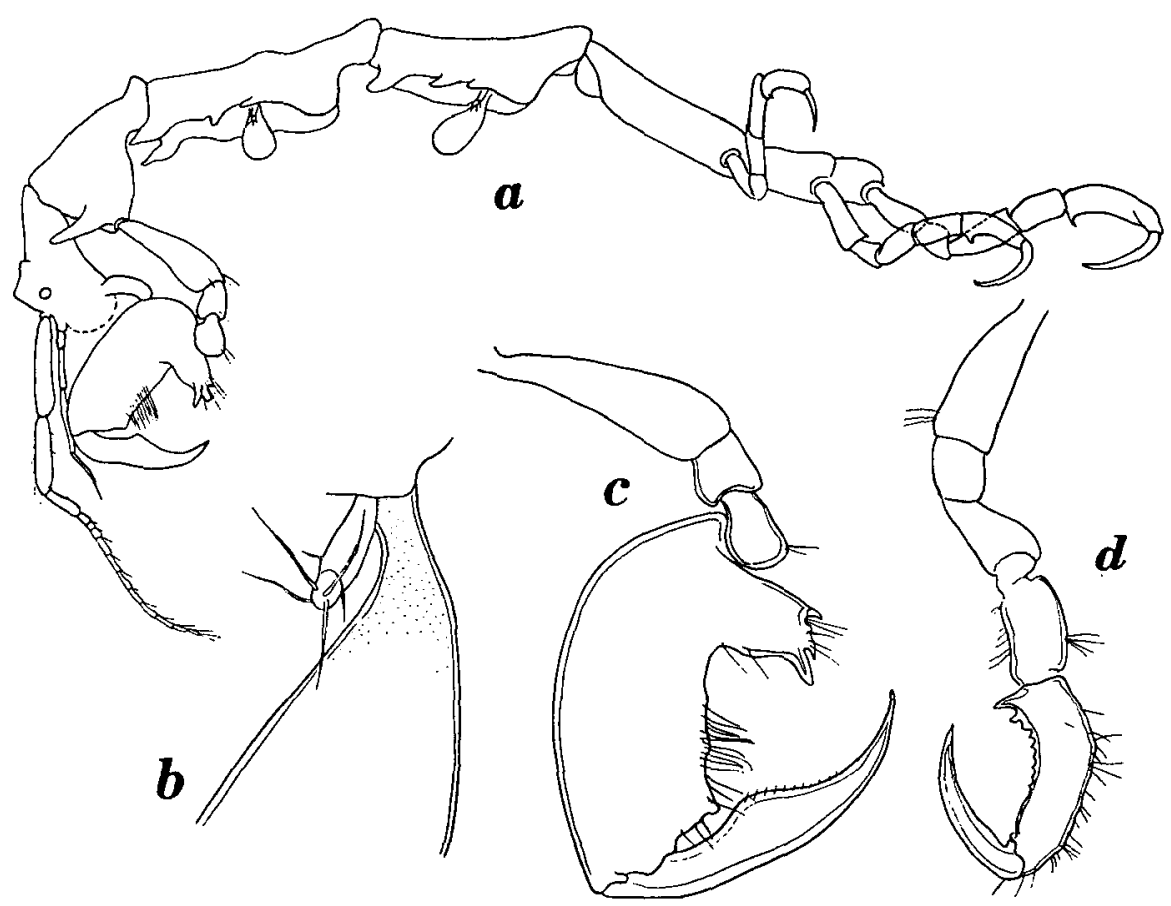

Fig. 4. Paracaprella crassa MAYER. $\delta$

$a$, Lateral aspect $(\times 16) . b$, Pereopod 4 at base of gill $(\times 144)$. $c$, Gnathopod $2(\times 34) . d$, Percopod $7(\times 34)$. 
Paracaprella [pusilla] MAYER, 1890, p. 41 (15 miles off Amoy, 8-25 fms, stony bottom).

Paracaprella crassa MAYER, 1903, p. 66, pl. 2, figs. 32-33, pl. 7, figs. 48-50 (Formosa Straits and Korean Straits); ARImoto, 1929, p. 8, pl. 1, fig. 3 (Tateyama, on Bugula); Utinom, 1947, p. 70 (Tanabe Bay).

Material.- 1 o. Off Ezura, southern coast of Tanabe Bay (by plankton-net.) Coll. T. Үамамото, 1940.

Description. - Body small, $5 \mathrm{~mm}$ long. Head shorter than pereonite 1, smooth, but quite angular just above small eyes, looking somewhat triangular as viewed from sides. Pereonite 1 smooth dorsally, distinctly bordered from head. Pereonite 2 terminating to a prominently raised knob and bearing a strong fore-directing spine above the base of gnathopod 2. Pereonites 3 and 4 subequal in length, with 3 bluntly pointed teeth on ventrolateral margin on both sides respectively. Pereonite 5 smooth, slender and slightly longer than pereonite 4 or a sum of succeeding pereonites 6 and 7 .

Antenna 1 about $1 / 3$ as long as body; peduncle 3 -jointed, rather plump; flagellum slender, 11-jointed, setose. Antenna 2 approximately the same as peduncle of antenna 1 in length, apparently not setose.

Gnathopod 2 peculiar, proximal angle of palm being truncatedly projecting and bearing 3 teeth at its end; dactylus with convex inner surface, tapering proximally and distally, minutely setose.

Pereopods 3 and 4 seated outside of base of gills rudimentary, 2-jointed, terminating into a few long setae.

Gills small, oval in form.

Pereopods 5-7 normal; palmar margin of 5th article slightly concave, serrate medially and strongly pointed proximally.

Abdomen with 2 pairs of simple pleopods.

Habitat and distribution.- Although Аrimoтo (1929, p. 9) found this species once on Bugula in Tateyama Bay, MAYER (1903, p. 66) recorded from deeper waters (22-30 $\mathrm{fms}, 28 \mathrm{fms}, 40 \mathrm{fms}$ ), as do the other species of Paracaprella. The present specimen was once found in plankton samples towed at a nearshore station in Tanabe Bay.

Hitherto known only from the oriental region.

\section{Caprella decipiens MAYER}

(Jap. name: Magire-warekara nov.)

MAYeR, 1890, p. 86, pl. 7, figs. 37-40 (Kadsiyama); Arimoto, 1930, p. 51 (p. 19 in repr.), fig. 6 (Tateyama); Hrro, 1937, p. 313, pl. 22, fig. 7 (Tanabe Bay); Utinomi, 1947, p. 73 (Tomioka and Mukaisima); Uтілом1, 1964, p. 14 (Tomioka).

Material.- 1 ㅇ (subadult). Off "Sirahama Bungalow", $1.5 \mathrm{~m}$ deep. Coll. T. TokiokA, March 12, 1966.

Habitat and distribution.- Endemic to Japan. 


\section{Caprella gigantochir MAYER}

(Jap. name: Tenaga-warekara Utn.)

(Fig. 5)

MAYER, 1903, p. 103, pl. 4, fig. 14 and pl. 8, figs. 7-9 (Enoura and Nagasaki); Arimoto, 1931, p. 10, fig. 7 (Tateyama); Hiro, 1937, p. 314, pl. 22, figs. 9-10 (Tanabe Bay); Utinomi, 1947, p. 74; UTiNomi, 1964, p. 14 (Tomioka).

Material.- 2令. Off "Sirahama Bungalow,", 1.5-1.8 m deep. Coll. T. TokiokA, March 12, 1966.

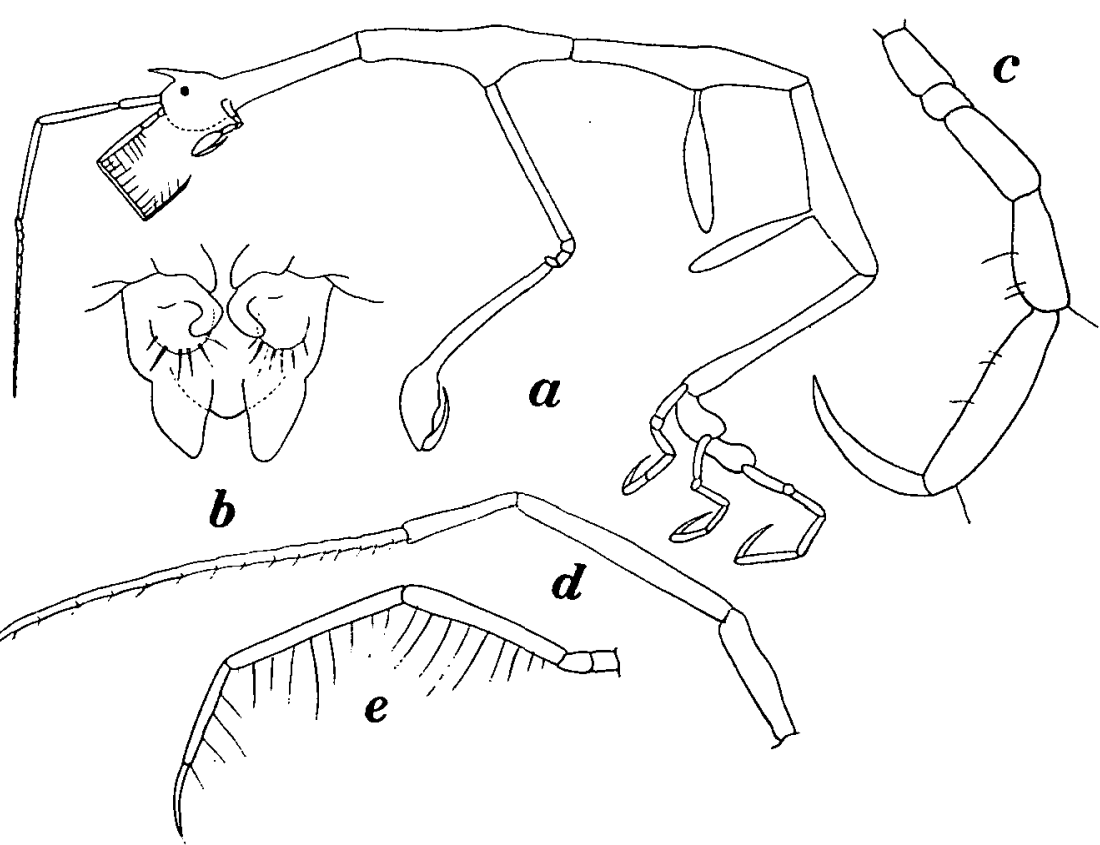

Fig. 5. Caprella gigantochir MAYer. \& $a$, Lateral aspect $(\times 5) . b$, Abdomen. $c$, Pereopod 5 $(\times 20)$. $d$, Antenna $1(\times 14) . e$, Antenna $2(\times 14)$.

Habitat and distribution.- Hitherto known only from southern Japan. Usually found grasping any sea weeds, but often solitarily taken by dredging or trawling at nearshore stations of sand bottoms.

\section{Caprella neglecta MAYER}

(Jap. name: Maruera-warekara Utn.)

Caprella acutifrons f. neglecta MAYER, 1890, p. 55, pl. 2, fig. 37, and pl. 4, figs. 57-58, 67-68; MAYER, 1903, p. 80; Uтімомт, 1943a, p. 273, figs. 2A and 3A; Utinomi, 1943b, p. 282, fig. 2; Utinomi, 1943c, p. 284, fig. 1; Utinomi, 1947, p. 72; Utinomi, 1964, p. 14. 
C. acutifrons var. natalensis MAYer.-Arimoto, 1930, p. 48 (p. 16 in repr.), fig. 3; Hıro, 1937, p. 312 , pl. 22, fig. 5 .

C. acuiffrons LATreille.- MAYER, 1882, pp. 48-50; IRIE, 1958a, p. 107.

C. neglecta MAyer.-VAssilenko, 1967, p. 200, figs. 5-6.

Material.- 10 令令. Station NS-1, off"Sirahama Bungalow", $1.5 \mathrm{~m}$ deep, Coll. T. TokiokA, March 12, 1966.

$7 \hat{\jmath}$ 今. Station NS-1, off "Sirahama Bungalow", $1.8 \mathrm{~m}$ deep, Coll.

T. TokiokA, March 12, 1966.

Habitat and distribution. - Commonest and very abundant all around the coasts of China and Japan, usually clinging to any seaweeds such as Sargassum and Zostera, etc. This caprellid is not uncommon on floating algae (cf. HrrosaKI, 1964) and often found in plankton samples, being released from floating algae (cf. IRIE, 1957, 1958a, 1958b, 1959).

\section{REFERENCES}

Arimoto, I, 1929. Studies on the Caprellidae from Tateyama, 1. Hakubutu-gakkaisi ( $=$ Hakubutugaku Zassi), 27 (38), pp. 1-11, pl. 1. (In Japanese)

- 1930. Idem, 2. Ibid., 28 (39) pp, 45-56, pl. 2. (In Japanese)

1931. Idem, 3. Ibid., 29 (41), pp. 10-19, pl. 3. (In Japanese)

BIERI, R. and T. Tokioka 1968. Dragonet II, an opening-closing quantitative trawl for the study of microvertical distribution of zooplankton and the meio-epibenthos. Publ. Seto Mar. Biol. Lab., 15 (5), pp. 373-390.

Chevreux, E. et L. Fage 1925. Amphipodes. Faune de France, 9, pp. 1-486.

Hiro, F. 1937. Caprellids from Tanabe Bay. Annot. Zool. Japon., 16 (4), pp. 310-317, pl, 22.

Hirosaki, Y. 1964. Ecological study on fishes with drifting sea weeds. III. Accompanying animals excluded fishes. Misc. Rep. Res. Inst. Nat. Res., (62), pp. 63-70. (In Japanese)

IrIE, H. 1957. Pelagic amphipods in the western seas of Kyusyu. Bull. Fac. Fish., Nagasaki Univ., (5), pp. 41-52.

1958a. Pelagic amphipods in Omura Bay. Ibid., (6), pp. 106-108.

1958b. Vertical occurrences of pelagic amphipods in neritic and inshore waters in the neighborhood of Sasebo. Ibid., (7), pp. 87-92.

1959. Studies on pelagic amphipods in the adjacent seas of Japan. Ibid., (8), pp. 20-24.

KıкUсні, T. 1962. An ecological study on animal community of Zostera belt, in Tomioka Bay, Amakusa Kyushu. (II) Community composition (2) Decapod crustaceans. Rec. Oceanogr. Wks. Jap., Spec. Number 6, pp. 135-146.

- 1966. An ecological study on animal communities of Zostera marina belt in Tomioka Bay, Amakusa, Kyushu. Publ. Amakusa Mar. Biol. Lab., Kyushu Univ., 1 (1), pp. 1-106.

Mayer, P. 1882. Caprelliden. Fauna und Flora Golfes von Neapel, mon. 6, pp. i-x, 1-201, pls. 1-10. 1890. Nachtrag zu den Caprelliden. Ibid., mon. 17, pp. i-vii, 1-157, pls. 1-7.

1903. Die Caprellidae der Siboga-Expedition. Siboga-Expeditie, mon. 34 (Livr. 12), pp. 1-160, pls. $1-10$.

McCain, John C. 1965. The Caprellidae (Crustacea: Amphipoda) of Virginia. Chesapeake Sci., 6 (3), pp. 190-196.

1966. Abyssicaprella galatheae, a new genus and species of abyssal caprellid (Amphipoda: Caprellidae). Galathea Report, 8, pp. 91-95.

SAndo, H. 1964. Faunal list of the Zostera marina region at Kugurizaka coastal waters, Aomori Bay, Bull. Mar. Biol. Sta. Asamushi, Tohoku Univ., 12 (1), pp. 27-35. [Caprellidae, identified by UTINOMI : 31$]$ 
Schellenberg, A. 1926. Die Caprelliden und Neoxenodice caprellinoides n. g. n. sp. der Deutschen Südpolar-Expedition 1901-1903. Deustch. Südpol. Exped., 18 (Zool. 10), pp. 465-476.

Stebring, Th. R. R. 1888. Report on the Amphipoda collected by H. M. S. Challenger during the years 1873-1876. Second Half. Rep. Sci. Res. "H. M. S. Challenger”, Zool., 29, pp. xxiv+1737, i-xii, pls. 1-210. [Caprellidae: 1226-1268, pls. 139-145.]

Utinomi, H. 1943a. Caprellids obtained in Onagawa Bay, northern Japan. Sci. Rep. Tohoku Univ., Ser. 4, 17 (3), pp. 271-279.

1943b. Report of the biological survey of Mutsu Bay. 37. Caprellids from Asamushi. Ibid., 17 (3), pp. 281-287.

1943c. The fauna of Akkeshi Bay. XIII. Caprellidea. J. Fac. Sci. Hokkaido Univ., Ser. 6, 8 (3), pp. 283-300.

1947. Caprellidae of Japan and adjacent waters. Seibutu, Supplementary, No. 1, pp. 68-82. (In Japanese)

- 1964. Caprellidae. Fauna and Flora of the sea around the Amakusa Mar. Biol. Lab., Part V. Amphipod Crustacea (T. KıкUCHI ed.), pp. 11-15, pls. 1-3.

- 1969. Caprellids from Kamaé Bay, northeastern Kyusyu (Amphipoda: Caprellidae). Publ. Seto Mar. Biol. Lab., 16 (5), (In press)

Vassilenko, S. V. 1967. Fauna of Caprellidae (Amphipoda) of the Possjet Bay (the Sea of Japan) and some data on their ecology. Issledovanija Fauny Morei, V (XIII), Biotzenozy Zaliva Possjet Japonskovo Morja, pp. 196-229. (In Russian) 